\title{
Are HIV Infected People Well Prepared to Travel? Polish Experience
}

\author{
Bartłomiej Mateusz Zalewski' ${ }^{1}$, Tomasz Mikuła2 ${ }^{*}$, Monika Romul¹, Monika Jabłońska1, \\ Iwona Cielniak ${ }^{3}$, Alicja Wiercińska-Drapało ${ }^{2}$ \\ ${ }^{1}$ Students Science Society of Department of Hepatology and Acquired Immunodeficiencies, Warsaw Medical \\ University, Warsaw, Poland \\ ${ }^{2}$ Department of Hepatology and Acquired Immunodeficiencies, Warsaw Medical University, Warsaw, Poland \\ ${ }^{3}$ Hospital of Infectious Diseases, AIDS Diagnosis \& Therapy Center, Warsaw, Poland \\ Email: ${ }^{*}$ tomasz.mikula6@wp.pl
}

Received 17 March 2014; revised 17 April 2014; accepted 30 April 2014

Copyright (C) 2014 by authors and Scientific Research Publishing Inc.

This work is licensed under the Creative Commons Attribution International License (CC BY).

http://creativecommons.org/licenses/by/4.0/

cc) (i) Open Access

\section{Abstract}

Introduction: This study aimed to identify knowledge about preparation for travel among Polish HIV infected patients. Materials and Methods: Our prospective questionnaire-based study assessed whether the abovementioned issues had an influence on travel plan decisions and whether HIV infected Polish people had any problems before and during travel. Results: All our 102 patients completed questionnaires. The majority sought pre-travel health advice. The mean duration of confirmed HIV infection was longer in travelers than in non-travelers $(p=0.02)$. More than half of travelers consulted with a physician prior to their journey but the most popular source of information about the health risks of travelling was the internet while a doctor's consultation was an alternative. Pre-travel prophylaxis was performed in less than $30 \%$ of patients. One of the most popular reasons for not travelling abroad was inadequate funds. Discussion: The situation of people with HIV in Poland is similar to that in other European countries. None of our patients had to give up their trip because of administrative barriers. HIV infected persons with a longer duration of infection were more willing to travel. One of the most popular reasons for not travelling abroad was inadequate funds. Among our patients, those afraid of potential health risks and inadequate funds are in the same proportion as in other countries. Conclusions: In our opinion, physicians should talk with HIV positive patients about their travel plans during routine visits. Polish HIV infected patients generally do not restrict their travel plans due to their HIV infection. The main sources of information for Polish HIV infected patients about possible problems during travel should be their doctor and additionally other sources of information like the internet.

\footnotetext{
*Corresponding author.
} 


\section{Keywords}

\section{HIV/AIDS, Travel, Consultation, Prophylaxis}

\section{Introduction}

According to the World Health Organization, at the end of 2012 there were approximately 35.3 million HIVpositive individuals living worldwide [1]. In the era of antiretroviral treatment we can observe an increased life expectancy of HIV infected people. Nowadays, more than $20 \%$ of HIV infected people travel to foreign countries every year [2]. However, there are also some pitfalls of travelling, not only for HIV infected individuals. There is a substantial risk of infection during international travel to some countries, especially when visiting tropical or subtropical areas [3]. HIV infected individuals have an increased risk of developing bacterial bloodstream infections, with a special focus on non-typhoid salmonellae bacteremia [4]. An HIV-positive status may alter the clinical course of diseases and infections which can be more severe [3]. An advanced HIV infection also increases the risk of opportunistic fungal infections [5]. According to the Duval et al. trial, pre-trip consultation reduces the morbidity of illnesses during travel [6]. In one of the studies, it was estimated that even $69 \%$ of HIV individuals had sought pre-travel consultation [7]. The other problem is that HIV infected patients encounter travel restrictions in certain countries. In previous years it has changed and nowadays a majority of countries do not restrict the entry or stay of HIV-positive individuals. Nevertheless, there are still regions in the world where difficulties, such as possible entry denial or deportation because of HIV infection, still exist [8]. An updated database of countries and their HIV specific travel and residence restrictions can be found on the internet [9].

\section{Materials and Methods}

To investigate the influence of an HIV positive status on an individual's decision to travel abroad and to identify administrative problems during travel abroad, we performed a survey study of individuals whose duration of confirmed HIV infection was at least 6 months. They were hospitalized in the Department of Hepatology and Acquired Immunodeficiencies of the Medical University of Warsaw or treated in the AIDS Diagnosis \& Therapy Center of the Infectious Diseases Hospital in Warsaw between January and December 2011. We decided to include people with a minimal time after diagnosis of half a year, as it is a reasonable minimum to ask about travel experiences in regards to HIV infection. In the questionnaires we assessed the HIV individuals' decisions on travelling abroad and reasons for resigning from such plans. We also asked about experiences during travelling abroad (countries, sources of information about potential health risks of travelling and problems if any occurred at the boarders).

\section{Results}

We analyzed a total of 102 questionnaires. The mean patient age was 41 years (range 23 - 70 years) and the mean duration of confirmed HIV infection was 9 years (range 0.5 - 25 years). Among all patients, 52 travelled abroad to at least one country after their infection was confirmed. We noticed that, the mean duration of confirmed HIV infections was longer in travelers than in non-travelers (10.3 years vs. 7.4 years, $p=0.02)$. More than half of travelers consulted with a physician prior to their journey. The most popular sources of information about the health risks of travelling and stay were the Internet and doctors' consultations. Pre-travel prophylaxis was performed in less than $30 \%$ of patients but some had been vaccined before-mostly against HBV and HAV. All of our patients asked about and began malaria prophylaxis before travel.

During travel, a few patients were asked about their HIV status-some because of suspicion of drug trafficking due to their anti-retroviral medicines being stored in personal luggage and one had to fill-in the questionnaire at the border, where there was a question regarding HIV infection. None of them were denied entry to the country of destination. One individual, potentially could have encountered a problem at the border, but checked on the country status before travelling and found out that entry for HIV people was denied at that time. In the nontravelers group - those patients who were not planning to travel at all mentioned potential health risks and a lack 
of funds as the main reasons for staying home. One individual cancelled a trip because of known HIV travel restrictions. The summary of all results is provided in Table 1.

\section{Discussion}

Poles went abroad mostly individually (15\%), and were slightly less likely to benefit from trips and visits organized by travel agencies (11\%) or to visit family, friends or acquaintances (also 11\%). In 2011, Polish borders were crossed by nearly 43.3 million Polish citizens traveling to other countries [10]. Among these people there were also HIV infected patients. According to our data about 50\% of HIV positive people who traveled abroad knew about their infection. Longer durations of HIV infection correlated positively with the decision about travelling $(\mathrm{p}<0.05)$. We can suggest that these people have better awareness of their illness and far more easily decide to travel. In the study Kemper et al. 1995 got comparable results of 46\% HIV infected travelling patients. More than $54 \%$ of our HIV infected travelers consulted with a specialist before their journey, which is less than the 69\% reported by Lortholary et al. 2013 [5]. The main reason was the lack of time and expectation to find sufficient information on the internet which was the most important source of knowledge about travelling or administrative related issues for our patients.

\begin{tabular}{|c|c|}
\hline Patients [n] & $\begin{array}{l}102 \\
\text { (52 travelers and } 50 \text { non-travelers) }\end{array}$ \\
\hline Age [mean; range] & 41 years; $23-70$ years \\
\hline Duration of confirmed HIV infection [mean; range] & 9 years; 0.5 - 25 years \\
\hline HIV infected travelers [n] & 52 \\
\hline Duration of confirmed HIV infection [mean; range] & 10.25 years; 1.5 - 25 years \\
\hline Pre-travel consultation with physician [n; \%] & $28 ; 54 \%$ \\
\hline $\begin{array}{l}\text { Travelers seeking information about health-related and administrative risks of } \\
\text { travel [n; \%] }\end{array}$ & $28 ; 54 \%$ \\
\hline Sources of information indicated by the travelers (multiple answers possible) [n] & $\begin{array}{l}\text { The internet-21 } \\
\text { Physician-14 } \\
\text { Friends-3 } \\
\text { Embassy-3 } \\
\text { Books and periodicals-1 }\end{array}$ \\
\hline Pre-travel prophylaxis (multiple answers possible) [n] & $\begin{array}{l}\text { Vaccination-14 } \\
\text { Influenza-8 } \\
\text { Hepatitis A-3 } \\
\text { Hepatitis B-4 } \\
\text { Tetanus-2 } \\
\text { Diphtheria-1 } \\
\text { S. pneumoniae-1 } \\
\text { Yellow fever-1 } \\
\text { Malaria prophylaxis-5 }\end{array}$ \\
\hline Administrative issues on border [n] & $\begin{array}{l}\text { Question about HIV status-6 } \\
\text { Questionnaire to fill-in-1 }\end{array}$ \\
\hline Travel plan changes [n] & $\begin{array}{l}\text { Known administrative problems on border-1 } \\
\text { Health related issues- } 1 \\
\text { Not stated }-2\end{array}$ \\
\hline Non-travelling HIV positive people [n] & 50 \\
\hline Duration of confirmed HIV infection [mean; range] & 7 years; 0.5 - 25 years \\
\hline Reasons for not travelling abroad [n] & $\begin{array}{l}\text { Did not plan travel-26 } \\
\text { Afraid of potential health risk-12 } \\
\text { Inadequate funds-12 } \\
\text { Other-2 }\end{array}$ \\
\hline
\end{tabular}


Less patients asked about pre-travel prophylaxis. The reason was that prophylaxis had been offered beforemostly against flu, HAV, HBV and Tetanus. Some had taken combinations of these vaccines previously or were in a safe period (less than 5 years after vaccination) like in tetanus prophylaxis. Malaria prophylaxis before travel was performed in all 5 our patients. This is a good example for the responsibility and knowledge of our patients. Despite the problem of making their decision about the trip, none of them were denied entry into the country of destination. A few people did report administrative-related issues during their journeys and it seems it is not a significant problem for Polish travelers. Mostly, additional explanations were requested by customs service, because of medicines in hand luggage. Only one patient decided to change their country of visit because of HIV related travel restrictions in the country of destination. Another one decided not to travel because of a high risk for his health (in his opinion). We suppose pre-travel consultation with a physician could decrease the number of non-travelers.

One of the most popular reasons for not travelling abroad was inadequate funds [7]. Among our patients those afraid of potential health risks and inadequate funds are in the same proportion. In comparison to the study of Kemper et al. where one fourth of non-travelers reported health related risks as another main reason of staying in the country of residence we got nearly the same results [11].

\section{Conclusion}

We suggest that during routine visits physicians should ask HIV positive patients about their travel plans, as they could not be aware of possible health and administrative pitfalls. Polish HIV infected people generally do not restrict their travel plans due to their HIV infection. We would like to promote discussion because doctors can give more information and we hope that the doctor's consultation will be the main source of information for Polish HIV infected patients maybe as a result of this small trial.

\section{Acknowledgements}

We would like to thank our all patients for patience and excellent cooperation.

\section{References}

[1] World Health Organization (WHO) (2013) Media Centre. Key Facts. (updated October 2013). http://www.who.int/mediacentre/factsheets/fs360/en/index.html

[2] Schuhwerk, M.A., Richens, J. and Zuckerman, J.N. (2006) HIV and Travel. Travel Medicine and Infectious Disease, 4, 174-183. http://dx.doi.org/10.1016/j.tmaid.2005.06.012

[3] Weitzel, T. (2012) Traveling with HIV. In: Hoffmann, C. and Rockstroh, J.K., Eds., HIV 2012/2013, MedizinFokusVerlag, Hamburg. www.hivbook.com

[4] Huson, M.A., Stolp, S.M., Van der Poll, T. and Grobusch, M.P. (2014) Community-Acquired Bacterial Bloodstream Infections in HIV Infected Patients-A Systematic Review. Clinical Infectious Diseases, 58, 79-92. http://dx.doi.org/10.1093/cid/cit596

[5] Lortholary, O., Charlier, C., Lebeaux, D., Lecuit, M. and Consigny, P.H. (2013) Fungal infections in Immunocompromised Travelers. Clinical Infectious Diseases, 56, 861-869. http://dx.doi.org/10.1093/cid/cis935

[6] Duval, B., De Serre, G.,Shadmani, R., Boulianne, N., Pohani, G., Naus, M., Rochette, L., Fradet, M.D. and Ward, B.J. (2003) A Population-Based Comparison between Travelers Who Consulted Travel Clinics and Those Who Did Not. Journal of Travel Medicine, 10, 4-10. http://dx.doi.org/10.2310/7060.2003.30659

[7] Simons, F.M., Cobelens, F.G. and Danner, S.A. (1999) Common Health Problems in HIV-Infected Travelers to the (Sub)tropics, Journal of Travel Medicine, 6, 71-75. http://dx.doi.org/10.1111/j.1708-8305.1999.tb00835.x

[8] Chang, F., Prytherch, M., Nesbitt, R.C., and Wilder-Smith, A. (2013) HIV-Related Travel Restrictions: Trends and Country Characteristics. Global Health Action, 6, 20472. http://dx.doi.org/10.3402/gha.v6i0.20472

[9] Wiessner, P. and Haerry, D. (2010) HIV Related Restrictions on Entry and Residence: Indicator of Stigma and Discrimination. EATG Activities at International AIDS Conference 2010, Vienna. Retrieved from: http://www.hivrestrictions.org/

[10] Bartoszewicz, W. (2011) Tourism Flows. Institute of Tourism, Warsaw Retrieved from: http://www.intur.com.pl/itenglish/statistics.htm

[11] Kemper, C.A., Linett, A., Kane, C. and Deresinski, S.C. (1995) Frequency of Travel of Adults Infected with HIV. Journal of Travel Medicine, 2, 85-88. 